Saudi Journal of Business and Management Studies Abbreviated Key Title: Saudi J Bus Manag Stud ISSN 2415-6663 (Print) |ISSN 2415-6671 (Online) Scholars Middle East Publishers, Dubai, United Arab Emirates Journal homepage: http://scholarsmepub.com/sjbms/

Original Research Article

\title{
Strategic Planning as a Tool for Enhancing Corporate Performance
}

\author{
Victor Biodun ${ }^{1 *}$, Hassan Barau Singhry ${ }^{2}$, Mohammed Nasir Ambursa ${ }^{1}$, Abiliu Christian ${ }^{1}$, Sotade Gabriel Akinwale ${ }^{3}$, \\ Ijeoma Onyeka Anaele ${ }^{4}$, Ogbu Uchechukwu Jeremiah ${ }^{5}$, Gwom Victoria ${ }^{5}$, Baba Aliyu Umar ${ }^{1}$, Umar Muz'au ${ }^{2}$, Ashikisu \\ Jatau Alex ${ }^{2}$, Akpabot Etebom Friday ${ }^{6}$ \\ ${ }^{1}$ Administrative Department, Federal College of Veterinary \& Medical Laboratory Technology, Vom, Plateau State, Nigeria \\ ${ }^{2}$ Faculty of Management Science, Abubakar Tafawa Balewa University, Bauchi, Nigeria \\ ${ }^{3}$ Molecular Biology Department, Federal College of Veterinary \& Medical Laboratory Technology, Vom, Plateau State, Nigeria \\ ${ }^{4}$ Library and Documentation Department, Federal College of Veterinary \& Medical Laboratory Technology, Vom, Plateau State, Nigeria \\ ${ }^{5}$ Administrative Department, National Veterinary Research Institute, Vom, Plateau State, Nigeria \\ ${ }^{6}$ Registry Department, National Defence Academic Kaduna, Kaduna State, Nigeria
}

DOI: $10.36348 /$ sjbms.2019.v04i11.002

| Received: 09.06.2018 | Accepted: 18.06.2018 | Published: 16.11.2019

*Corresponding author: Victor Biodun

Abstract

This paper work aims at examining the strategic planning as a tool for enhancing corporate performance and analyses strategic planning tools and its implementation process. However, it has been noticed that organization are no longer seen to be focused and real. Evidence of actionable plans are no longer there in our organization as indication of appropriate strategic plan. A study was conducted into books of notable authors written on strategic planning and corporate performance and selected ideas are compiled in this paper report. Data used for analysis were collected through questionnaires and interview conducted. It was discovered that organization adopts strategic planning; it was also found that strategic planning is effective in organization policy. Finally, having discovered that strategic planning contributes to the profit of an organization and it equally has impact on the corporate performance in an organization. The paper recommends that as a result of effectiveness of strategic planning, organization should continue to adopt it and give more priority and also government should create enabling economic environment that will make strategic planning a fruitful weapon.

Keywords: Strategic planning, effectiveness, tool for enhancing, corporate performance.

Copyright @ 2019: This is an open-access article distributed under the terms of the Creative Commons Attribution license which permits unrestricted use, distribution, and reproduction in any medium for non-commercial use (NonCommercial, or CC-BY-NC) provided the original author and source are credited.

\section{INTRODUCTION}

Strategic planning is a method used by an organization to anticipate and adopt to expected changes. It is long term plans based on the organization overall business objectives: it involves creating an action plan based on clear end results and accurate assessment of current reality. It is also waved as the planning activity through which one confronts the major strategic decisions facing the organization. A decision is not rendered strategic merely by being important.

The need for corporate performance in the industries cannot be over emphasized. Focus is placed on the important things: resources (time, talent, money) are properly allocated to those activities that provide the most benefit. Companies become aware of the company's potentials in light of its strengths and weakness identify and available opportunities and potential threats and also gain a sense of security among employees that comes from better understanding of the changing environment and the company's ability to adopt. Also poor performing areas can be identified and eliminated and growth can be accelerated and improved.

Industries today show glaring dwindling performance in their activities. Industrial process does not produce plan that is real. There is no longer evidence of adequate external focus any sufficient use of outsiders, no actionable plan in most industries today. It does not seem as if anybody is doing anything 
most companies are getting lost in executing tactics but missing the big picture.

Most organization do not comprehend strategic planning, they thought that a simple plan is appropriate for success. However, if a strategy is wrong at first place, the second chance may be difficult.

A look at our industries today depicts a dwindling performance compared to expectations. Organizations are no longer seen to be focused and real. Evidence of actionable plans is no longer there in our organization on indication of appropriate strategic plan. There is lack of measurable growth and development in our corporate world and this is a big concern to the business world. Companies no longer declare real and sustainable profit to match with planned goals and objects of such organization. Some of these problems rise by question on the strategic management process in our organization and the reason for the research work into strategic planning as a manager tool for corporate performance.

The objective of this paper is to review some known literatures relevant to this study. This review of related literatures is to enable the publishers know what other writers or scholars said and have written in respect to the study. Many papers have been written on related ideas regarding this topic, thus many of them would be reviewed by the writers and draw back if any shall be identified.

\section{MATERIALS AND METHODS}

The paper depends on both primary and secondary source of data. To generate the primary data a field survey was conducted through the use of questionnaires. Therefore, the paper was quantitative as some relevant journals, textbook, paper representation and to a large extent internet (website) of some scholars. This paper is basically non-empirical since information is collected directly without changing the environment.

\section{The Concept of Strategy}

Most definition of strategic is based on individual perspective depending on the specialization area being focus by the writers. Some of these were examined in the subsequent paragraphs.

We are living a dynamic world were change is the order of the day. The Greek philosopher Heraclites (536-470BC) held that "all things are in state of continual flux and nothing is permanent but changes". Therefore it seems that we cannot block the flow of change. Change in organization is part of a wider pattern of change in the world at large.

Contrasting the earlier stable organizational world of the 1950's and the 1960's with the comment reality [5] are of the opinion that today's companies and environment are more similar to the weather than to the precise assembly line system typical of Newtonian thinking faced with the reality of this unpredictability to survive and grow business organization and plan new strategies day by day that will enable them actualize the overall objective of the firm.

Although the application of concept of corporate strategy in business management recent its importance in business cannot be over emphasized. It has attracted the attention of many captains of industry; business executives and the academic all over the world. Ayo, O [4] argues that strategy is regarded as a crucial element in warfare depending on its successful and careful application battle may be won or lost as in war so it is in business compilation.

Jill and Ogilvie [8] defined strategy as a though out plan or action, a consciously formulated broadly defined policy for achieving an objectives. Peace Robinson [10] defined it as the determination of the long-term goals and objective of an enterprise and the adoption of courses of action and the allocation of resources necessary to carry out these goals.

Adah, G. B. E [1] define strategy as the pattern of plan that integrates an organizations major goals and objectives policies and actions sequential into a cohesive whole.

The important things to note about the various definition of strategy include:-

- Strategy is a plan, which is integrated, unified and comprehensive.

- Strategy planning results into a viable posture for the organization.

- Strategy is based on organization strength and weakness i.e. (competence).

- Strategy requires proper executions and implementation through structured policy leadership.

- $\quad$ Strategy is based on defined objectives.

Strategic planning work effective with the aid of the followings:-

- Policies: Policies are guides to actions, they indicate how resources are to be allocated and how task are to be accomplished. Policy is a rule that expresses the limits within which action is to taken place. They guide lower level management and the employees on how to behave and take decisions. Policies help to resolved conflicts, like objectives policy exist in a hierarchy throughout the organization.

- Programmes: Programmes specified the step by step sequence of actions necessary to activates within a limit set by policy programmed. Ensure that resources are committed at the right time. They also provided this target which provides this target in which progress can be measured. 


\section{OBJECTIVES}

Objectives or goals state what is to be achieved and where result are to be expected the target performance.

According to Donnelly, A [6] "Organization objectives are the end point of an organization's mission and are what is seeking through the ongoing run operations of the organization.

- Organizations tend to have multiple objectives.

- Organization objectives exit in hierarchy or priority.

- Valve objectives

- Achievement or performance objectives. There are different ways to measure objective some of them are

(a) Efficiency and

Dfficiency is related to cost of achieving your target (cost achieve money).

$>$ Effectiveness has to do with the degree to success for achieving the set objectives.

\section{Types of Objectives}

There are variation of objectives that organization persuades, some in the long run, while other in the short run, the most important including the following:

1. Profit Maximization: - is a very important objective in private sectors organization but in most cases it's not attainable. For example for you to maximize profit, you must have sufficient information on short term and long term cost and choose a line of action will help to attain the highest difference between Marginal Cost (MC) and Marginal Revenue (MR). In practice managers don't normally have this information instead they attempt to achieve maximum profit. However, most managers behaved in such away as to suggest that they are pursing profit maximization sales revenue instead of profit.

2. Sales Revenue Maximization: - Quite often manager's pursuit strategies that will help maximize sales revenue instead of profit.

3. Growth: - most managers' pursuit to see that their organization grows. Most managers try to see that the size of the organization increases. When you are to pursuit growth when you cannot maximize profit in the long run but objective are quite compactable.

4. Market Share: - It is one of the management objectives because in oligopolistic market the market share is very important in determining profit.

5. Return on Investigation (ROI):- many at times managers set target on return on investment which serves as investment hard rate
6. To Improve Quality of Services to Customers: - it is one of the managerial objectives to achieve customer satisfaction so as to maintain the goodwill of the business.

\section{Characteristics of Objectives in Regards to Strategy}

1. They pursue multiple objectives.

2. Objectives have time dimension that is some have short term and long term.

3. Objectives are measureable, objectives are prioritized which means some objectives are considered most important at a particular time.

4. Objective exists in hierarchy, corresponding with the structure of an organization (top management objectives). The lower you go in an organization the more details the objectives. At lower level of organization objectives tend to be short-term.

5. There are many ways to measures objectives some are efficiency measures and some are effective measures. Efficiency measures have to do with the degree or extent to which the objective can be fully realized.

6. There are limits in the attainment of objectives, if you want to achieve efficiency there is a limit because you cannot achieve beyond the level of efficiency.

7. Finally, objectives are not strategies but objectives give rise to strategy. Strategies are in need to the attainment of objectives.

\section{Need For Planning}

Asen, E. A [3] is of the opinion that the fundamental purpose for all managerial planning is to establish and help achieve organization objectives. At the very top level of organizations, managers set overall objectives and strategies for achieving them. At lower levels, managers formulate goals and plan in progressively narrower areas to support the accomplishment.

\section{Problems of Planning}

- Life Span: The greater the first span the greater the type of mistake present conditions are usually dominant in the planners mind when he initiates the plan and this may be over stressed.

- Unforeseen Event and Lack of Communication: Many events are obviously unforeseen but planning can be aided by techniques giving suggested probability of events taking place. Wider co-station of workers is needed to enable them understand the nature of obstacle and reasons for taking certain course of action to overcome them.

- Size of Organization: The larger the scope of the plan the more complex the planning e.g. plan for a department and plan for a group of department.

\section{Importance of Planning}

Eric, P [7] say that planning is the process of deciding in advance what is to be done and how it is to 
be done. Effective planning and decision making are metrically linked for without decisions and actions the planning process is a sterile exercise. The following constitute the importance or reasons why business organizations should plan.

- Planning provided motivation to other to support the business.

- A planning plan necessitates logical through process so that you know in which direction you are headed.

- A plan serves as a measurement and evaluation tool helping to determine whether goals have been met.

- It can highlight future problems and opportunities at the early stage.

- It is a communication tool for staff motivation; target can be used to measured staff performances and incentives.

- A business plan that reflects successful analysis of businesses potential will more likely attract financing.

- Planning promotes literal thinking and facilities brain storing session.

\section{Strategic Planning}

Strategic planning is a formal and systematic process. It is long-term and different than short-term or annual budgeting. Its primary purpose is to determine the current position of the organization and its future direction. The planning horizon is usually three (3) to ten (10) years. Strategic planning is objective oriented and focuses on specific measureable actions. It is based on available and factual information and assumptions regarding the future. It clarities relationships, promotes understanding of established objectives and assigns specific responsibilities, tasks and time schedules. It includes orderly review of progress.

Strategic planning uses the organization strength to put in best possible position while change is occurring. It also devises steps to minimize the organizations weakness or even better, devises steps that turn weakness into strengths. Strategic planning helps obtain the confidence of leaders and investors. It evaluates alternative actions. In short, strategic planning makes a organization proactive instead of reactive.

It was view that strategic planning is a step by step guide crested by business organization to map out how it will reach goals. It is a foundation for the entire organization. So everyone knows what will happen and what is expected of them in the process. It is also a receipt for achieving a stead vision strategic planning can also be viewed as a management tool for:

- Problem solving

- Market planning

- Product development

- Preparation of business plan
- Provides a road map or a sense of direction to an organization.

Element of Strategic Plan

It contains the following element:-

- Vision of the organization

- A mission statement

- Critical success factor

- Strategic and action

- Prioritized implementation schedule

\section{Corporate Strategy}

This is the strategy that address on the question what type of business should company be in? Adeniyi, A [2] put in succinctly when he said corporate strategy is the pattern of decision in a company that determines and reveals its objectives purpose or goals, procedure, the principle policies and plans for achieving those goals and defines the range of business the company is to pursue the kind of economic contribution it intend to make to employees customer and communities.

\section{Competitive or Business Strategy}

This is concerned with decision about how to compete in a particular market competitive strategy is therefore likely to focus on individual unit product or market within the organization. It also concerned with how difference functions of the organization like marketing, manufacturing, accounting and finance, information technology etc contribute to the higher level of strategy.

\section{Characteristics of Effective Strategy}

For a strategy to be effective it must possess the following:-

- Comprehensive: A strategy is said to be comprehensive if it covers all major aspects of the organization.

- Integrative: A strategy is said to be integrative when all components parts are compatible with another and fit smoothly together.

- Dynamic: A strategy needs to be dynamic because it must be flexible enough to meet the constantly changing environment in which organizations exit and operate.

- Timeliness: The final distinguishing quality of an effective strategic is the issue of time when it is initiated the best idea and plan of action can fail if it is initiated at the incorrect time. Therefore, when instituting at the incorrect time. Therefore, when instituting a particular strategy we must give a careful consideration to social, political and economic, legal and technological environment as well anticipated.

\section{Benefit of Strategic Planning}

- Focus is placed on the important things resources (time, talent, money) are properly allocated to those activities that provide the most benefit. 
- Prove an awareness of the changing environment as a foundation for needed change.

- Analyze the internal business culture and evaluate is impact on the company's performance.

- Recognize the impact the company and affect the needed changes in direction.

- Become aware of the company's potential in light of its strength and weaknesses.

- Identify and analyze available opportunities and potential threats.

- Strategic issues can be brought up for management.

- Able to set move realistic objective that are demanding yet attainable.

- Gain control of operational problems.

- Develop a frame of reference for budgets and short range operating plans.

- Provides a road map to show where the company is going and how to get there.

\section{The Roles and Task of the Strategic Planning}

The roles and task of the strategic planning, Nwanchukwu, C. C [9] say that if senior and middle managers have the lead roles in strategic making and strategic implementing their areas of responsibility.

What should strategic planning do? If there is legitimate place in big companies for a strategic planning department staffed with specialist in planning department role and task should consist chiefly of helping together and organize information that strategic makers need. Establishing and Administering an annual strategic plans and coordinating the process of reviewing and approving the strategic plans developed for all the levels crystallize; the addition, they can provide date help analyze industry and competition condition and distribute information in the company's strategic performance. But strategic planners should not make decisions, prepare strategic plans.

\section{Strategic Management Model}

The strategic management model contains some steps. These are as follows:-

- Mission and objectives

- Alternative and strategies

- Emotional analysis (opportunities and threats) more place with their own decision than they would be with authoritarian decision.

\section{Effect of Strategic Management}

The effect of strategic management can be categorized into five:

1. Strategic formulation activities enhance the firm's ability to prevent problems. Managers who encourage subordinate attention of planning and aided in their monitoring and forecast responsibilities by subordinate who are aware of the needs of strategic planning.

2. Group based strategic decisions are likely to be drawn from the best available alternatives. The strategic management process results in better decision because group interaction generates a greater variety of strategies and because forecasts based on the specialized perspectives of group members improve the screening of opinions.

3. Involvement of employees in strategy formulation improves their understanding of the productivity, reward relationship in every strategic plan and thus, heightens their motivation.

4. Gaps and overlaps in activities among individuals and group are reduced as participation in strategy formulation activities difference in roles.

5. Resistance to change is reduced. Though the participants in strategy formulation may be as more placed with their own decision than they would be with authoritarian's decision.

\section{CONCLUSION}

Conclusively, the increasing rate of strategic planning in the Nigeria business landscape is one of the welcomed tools for organizations. This has been studies by some researchers either towards establishing range if problems that contend with the development of strategic planning to a tool in examine the perception of enhancing their corporate performance towards geared in the direction if balancing the perceived mission of the organization with that is actually obtainable.

However, the changes in the world of business and similar ones take place around the world have led to a different approach to managing business.

From the above therefore, strategic plan is one of the major weapons in managerial skill cannot be neglected in either profit public or private organizations as well as either profit or non-profit making organizations. The study also shows that no planning is an ongoing plan and its effectiveness can be evaluated by the extent to which an organization is able to harness its opportunities and changes in the business environment. The major findings of this research were that strategic planning is an effective tool for enhancing corporate performance.

\section{RECOMMENDATION}

In the view of the finding above the researchers wishes to recommend the following that will help increase the effectiveness of strategic planning.

- Due to the effectiveness of strategic planning organizations should continue to adopt it in all areas of its operations.

- Management should give more priority to strategic planning because it would lead to expansion growth through profit enhancement. 
- As a result of positive impact on the corporate performance of the organization. Strategic planning should or continuously implemented.

- Government should provide an enabling economic environment that will make organization attain maximally from adopting strategic planning as a way forward.

\section{REFERENCES}

1. Adah, G. B. E, (2003). Corporate survival in the sector of the Nigeria Economy. The Nigeria Journal of Management Research (Jos), 3.

2. Adeniyi, A. (2004). An insight into Management Accounting: (3rd Edition). GLTODA Ventures LTD.

3. Asen, E. A. (2006). Principles and practical approach to Management: New Era Production, Bauchi.
4. Ayo, O. (2004). Management and strategy Text and Practice: Lagos ELTODA Ventures LTD.

5. Daft \& Lengal, (1994). The challenges of chaos in Teaching Tips: Management Orlando Harcourt Braco.

6. Donnelly, A. (1981). Fundamentals of Management. (6th Edition) Business Publication INC. 1981 USA

7. Eric, P. (2005). Strategic Planning in an Organization. Google search.

8. Jill \& Ogilvie. (2005). An empirical Text of cognitive style and strategic outcome. Journal of Management Studies, 42(2). UK. Black well publishing.

9. [9] Nwanchukwu, C. C. (2004). Management Theory and Practice Africana $1^{\text {st }}$ Publishers.

10. Peace, R. (2003). Strategic Management formulation, implementation and control (8th Edition) MC-Graw-Hill Companies. 